\title{
EFFECT OF MICROBIOLOGICAL CHARACTERISTICS OF RAW MILK ON THE QUALITY OF WHOLE MILK POWDER
}

\author{
Carlos Augusto Fernandes de Oliveira ${ }^{1 *}$; Lucinéia Mestieri ${ }^{1}$; Marcos Veiga Santos ${ }^{1}$; José Franchini Garcia Moreno ${ }^{1}$; \\ Aleksandrs Spers' ${ }^{1}$; Pedro Manuel Leal Germano ${ }^{2}$ \\ ${ }^{1}$ Departamento de Nutrição e Produção Animal, Faculdade de Medicina Veterinária e Zootecnia, Universidade de São Paulo, \\ Pirassununga, SP, Brasil. 'Faculdade de Saúde Pública, Universidade de São Paulo, São Paulo, SP, Brasil.
}

Submitted: June 07, 1999; Returned to authors for corrections: March 24, 2000; June 26, 2000

\begin{abstract}
The relationship between microbiological characteristics of raw milk and the quality of high-heat whole powder made from it was investigated. To this end, 16 lots of milk standardized for fat and non-fat solids were used. Powder average levels of mesophiles and psychrotrophs were $7.8 \times 10^{1}$ and $4.0 \times 10^{1} \mathrm{CFU} / \mathrm{g}$, respectively, and these values correlated positively $(\mathrm{P}<0.05)$ with the corresponding raw milk counts $(8.1 \mathrm{x}$ $10^{6}$ and $1.8 \times 10^{7} \mathrm{CFU} / \mathrm{g}$, respectively). A significant positive correlation $(\mathrm{P}<0.05)$ was also observed between raw milk psychrotroph counts and titratable acidity of milk powder (range: $0.15-0.19$ as \% lactic acid). Samples of powder produced from raw milk with higher psychrotroph levels were found to have higher insolubility indexes, yet this relationship was not statistically significant. The importance of milk hygienic control as a basic instrument to warrant commercial milk powder quality is discussed.
\end{abstract}

Key words: milk powder, microbiological quality, physical and chemical quality

\section{INTRODUCTION}

Milk powder is generally considered a product of good microbiological quality. However, several factors may contribute to changes in its physical and chemical properties which reduce shelf-life and thus its commercial value (4). Different researchers agree that the hygienic conditions under which raw milk is produced are the main factor affecting powder quality $(10,12$, 15). Storage temperature and transportation may also influence the properties of milk powder, especially its insolubility index and acidity (5).

In Brazil, raw milk used by powder manufacturers is required to match at least the same characteristics of Grade C Milk, for which no threshold levels have been established on microbiological parameters such as total bacterial count and pathogenic bacteria (11). Therefore, some dairy industries has set their own standards on the quality of raw milk purchased for processing.
The regulations on microbiological quality of milk powder in Brazil have established maximum levels for mesophilic bacteria, coliforms (at 30 and $45^{\circ} \mathrm{C}$ ), Staphylococcus coagulase positive and Salmonella species (13). Efforts of dairy plants to meet standard requirements have traditionally concentrated on applying high temperatures in order to reduce initial bacterial loads of poor quality raw milk. This method, however, has been associated with low powder quality, mainly with respect to offflavors, color changes and reduced stability after reconstitution $(9,14)$.

Brazil produces nearly 230.000 tons of milk powder/year, which account for almost $25 \%$ of its total annual milk production (3). However, little information is available on factors that affect the quality of milk powder in the country. In view of this, the aim of the present study was to investigate the possible correlation between microbiological characteristics of raw milk and the quality of the resulting milk powder manufactured under local conditions.

\footnotetext{
* Corresponding author. Mailing address: Departamento de Nutrição e Produção Animal (VNP - FMVZ - USP), Rua Duque de Caxias Norte, 225, Caixa.Postal 23, Pirassununga, SP, CEP 13630-000, Brasil. Fax: (+5519) 561-6215, E-mail: carlosaf@usp.br
} 


\section{MATERIALS AND METHODS}

\section{Sampling procedure}

Sampling procedures were carried out in a commercial dairy plant located in the State of Minas Gerais, Brazil, during June to October, 1997. Raw milk previously stored at 4 to $7^{\circ} \mathrm{C}$ was standardized in order to obtain a fat/non-fatty solids ratio of 0.395 . Heat treatment of raw milk included pasteurization at $90^{\circ} \mathrm{C}$ for $8 \mathrm{~s}$ and an uperization step at $108^{\circ} \mathrm{C}$ for $2 \mathrm{~s}$. Heat treated milk was then concentrated to $48 \%$ total solids in a triple effect evaporator (average temperature of $50 \pm 4^{\circ} \mathrm{C}$ ). After concentration, milk was spray dried by atomization and simultaneous direct injection of air at $270^{\circ} \mathrm{C}$.

Duplicate milk samples of the 16 lots used were collected at 3 different stages during processing, namely: a) standardized refrigerated raw milk stored in silos; b) concentrated milk; and c) milk powder, collected immediately after drying and cooling. All samples were placed in sterilized glass tubes and transported to the laboratory of dairy plant under refrigeration (in an isotherm recipient with ice), for immediate evaluation.

\section{Microbiological analyses}

Microbiological analyses were performed on samples of raw milk, concentrate and powder, following the procedures of the American Public Health Association (2). Using a sterile blender, $25 \mathrm{~g}$ of sample were homogenized with $225 \mathrm{ml}$ of $0.1 \%$ peptone saline solution. Then, according to each sample, tenfold serial dilutions up to $10^{-6}$ were prepared using the same diluent and subsequently plated onto standard plate count agar medium (PCA) (Oxoid). Psychrotroph counts were determined after incubation at $7^{\circ} \mathrm{C}$ for 10 days. Mesophile and thermophile counts were obtained after incubation at $32^{\circ} \mathrm{C}$ for $48 \mathrm{~h}$ and $55^{\circ} \mathrm{C}$ for 48 $\mathrm{h}$, respectively.

\section{Physical and chemical analyses}

Powder samples were assayed for titratable acidity (\% lactic acid) and moisture content according to the Analytical Methods of the Instituto Adolfo Lutz (6). Additionally, a reconstitution test was performed using the insolubility index method described by the American Dry Milk Institute (1).

\section{Statistical analyses}

Average results of duplicate samples of the 16 lots were submitted to statistical analyses in order to determine Pearson's Correlation Coefficient (r) between parameters. The number of colony forming units (CFU) was transformed to $\log 10$. A Student t test, with normal approximation, was used to compare correlation values (7) at a 5\% level of significance.

\section{RESULTS AND DISCUSSION}

The bacteriological quality of raw milk, concentrate and milk powder is shown in Table 1. The number of decimal reductions for mesophile and psychrotroph counts was 5 to $6 \log$ cycles, which meets the microbiological standard established by Brazilian regulations (13) for aerobic mesophile counts (maximum of $3.0 \times 10^{4} \mathrm{CFU} / \mathrm{g}$ ). The effectiveness of heat treatment in reducing bacterial load in milk powder was similar to that previously observed during production of spray-dried milk powder $(5,8,12)$. Little change in thermophile counts with each processing step has been reported (5).

Table 1. Microbiological analysis of raw milk, concentrate and powder. Results are expressed as geometric means.

\begin{tabular}{lccc}
\hline Parameter & Raw milk & Concentrate & Powder \\
\hline & & CFU/g & \\
Mesophile & $8.1 \times 10^{6}$ & $1,6 \times 10^{2}$ & $7.8 \times 10^{1}$ \\
& $\left(8.2 \times 10^{4}-6.9 \times 10^{7}\right)^{\mathrm{b}}$ & $\left(1.0 \times 10^{1}-9.2 \times 10^{2}\right)$ & $\left(1-5.6 \times 10^{2}\right)$ \\
Psychrotroph & $1.8 \times 10^{7}$ & $4,2 \times 10^{2}$ & $4.0 \times 10^{1}$ \\
& $\left(5.0 \times 10^{4}-2.0 \times 10^{7}\right)$ & $\left(1.5 \times 10^{1}-6.4 \times 10^{3}\right)$ & $\left(1-2.2 \times 10^{2}\right)$ \\
Termophile & $8.0 \times 10^{0}$ & $1.7 \times 10^{1}$ & $2.3 \times 10^{1}$ \\
& $\left(1-1.0 \times 10^{3}\right)$ & $\left(1-9.5 \times 10^{2}\right)$ & $\left(1-6.4 \times 10^{2}\right)$ \\
\hline
\end{tabular}

${ }^{\text {a }}$ Mean of duplicate analyses of 16 lots examined

b Range values.

Data from the physical and chemical analyses are presented in Table 2. There was little variation in the moisture content and titratable acidity of powder, as also observed by Griffiths et al. (5) in skimmed milk powder after low-heat processing (pasteurization at $74^{\circ} \mathrm{C}$ for $16 \mathrm{~s}$ ). Insolubility indexes varied from 0.27 to $0.45 \mathrm{ml}$, hence being within the range of Brazilian standards (11) and also in accordance with the ADMI (1) recommendations. However, if we were to take into consideration Spreer's upper limit of $0.3 \mathrm{ml}$ for powder manufactured by a spray-drying process (14), then 11 out of our 16 lots analyzed would be above the recommended insolubility index.

Table 2. Average values of physical and chemical characteristics of milk powder.

\begin{tabular}{lc}
\hline Parameter & Mean $^{\mathrm{a}}$ \\
\hline Titratable acidity (\%) & $0.17(0.01)^{\mathrm{b}}$ \\
Moisture (\%) & $2.84(0.13)$ \\
Insolubility index (ml) & $0.36(0.09)$ \\
\hline
\end{tabular}

${ }^{\mathrm{a}}$ Mean of duplicate analyses of 16 lots examined.

${ }^{\mathrm{b}}$ Standard deviations are between brackets.

The statistical analyses indicated a positive correlation between mesophile and psychrotroph counts of raw milk and milk powder, as shown in Table 3. These findings agree with reports by Lück (10), who, as was the case in the present study, 
applied a high intensity heat treatment to reduce bacterial loads in raw milk and found similar correlations. With respect to thermophile counts, however, we found no significant relationships $(\mathrm{r}=0.03, \mathrm{n}=16)$. This is consistent with earlier findings by Kwee et al. (8), who likewise compared high-heat raw milk and powder for thermophile as well as thermoduric and spore-forming organisms (8).

Table 3. Correlations (r) between microbiological, physical and chemical characteristics of raw milk and powder.

\begin{tabular}{lc}
\hline Parameters & Correlation (r) \\
\hline Mesophiles & $0.77^{*}$ \\
Mesophiles x Titratable acidity & 0.45 \\
Mesophiles x Insolubility index & 0.35 \\
Mesophiles x Moisture & 0.11 \\
Psychrotrophs & $0.69^{*}$ \\
Psychrotrophs x Titratable acidity & $0.64^{*}$ \\
Psychrotrophs x Insolubility index & 0.45 \\
Psychrotrophs x Moisture & 0.12 \\
Termophiles & 0.03 \\
Termophiles x Titratable acidity & -0.37 \\
Termophiles x Insolubility index & -0.38 \\
Termophiles x Moisture & 0.35 \\
\hline
\end{tabular}

$*$ significant $(\mathrm{P}<0.05)$.

There was a slight increase in the titratable acidity of milk powder manufactured from milk with higher mesophile and psychrotroph counts, yet this chemical parameter correlated significantly only with the latter $(\mathrm{r}=0.64, \mathrm{n}=16, \mathrm{P}<0.05)$. These results differ from powder quality data from other authors (12); in their study, on the other hand, raw milk was submitted to a single low intensity heat treatment during processing, unlike the present investigation. Since the titratable acidity of milk is augmented by formation of organic acids due to heat (9), the high temperature used in our experiments may have contributed to increased acidity values in the powder manufactured from raw milk with higher counts for psychrotroph organisms.

We found no correlation between moisture content of the powders and the microbiological parameters studied. In fact, moisture variations of powders are more frequently associated with failures during the atomization procedure, and with changes in the composition of the standardized milks (14).

The main factors that increase insolubility indexes are high temperature applied to raw milk and the load of psychrotroph bacteria $(9,14)$. In the present study, the correlation between raw milk psychrotroph counts and milk powder insolubility was positive but not statistically significant $(\mathrm{r}=0.45, \mathrm{n}=16)$. Similar results were obtained by Griffiths et al. (5) using raw milk with psychrotroph counts from $3.1 \times 10^{5}$ to $4.3 \times 10^{8} \mathrm{CFU} / \mathrm{ml}$.
Data from several authors indicate that psychrotroph numbers exceeding $1 \times 10^{7} \mathrm{CFU} / \mathrm{g}$ may result in physical and chemical changes, as well as defects in the functional properties of milk powder $(4,10,15)$. This occurs mainly because of the appreciable amounts of degrading enzymes secreted by the psychrotroph flora (4). Thus, control of these microorganisms in milk is of great importance to the dairy industry.

To conclude, the results of the present study indicated a positive correlation between mesophilic and psychrotroph counts of milk powder and the hygienic conditions of raw milk used for processing. Raw milk psychrotroph counts were also negatively associated with titratable acidity levels in milk powder. Our data demonstrate the importance of reducing microbiological loads of raw milk in order to obtain a high quality milk powder under our local conditions.

\section{ACKNOWLEGDEMENTS}

The authors thank the Fundação de Amparo à Pesquisa do Estado de São Paulo (FAPESP, Brazil; grant nº 96/1972-9) for financial support.

\section{RESUMO}

\section{Efeito das características microbiológicas do leite cru sobre a qualidade do leite em pó integral}

Neste trabalho, avaliou-se a relação entre a qualidade do leite em pó integral e os principais parâmetros microbiológicos do leite empregado como matéria-prima, utilizando-se 16 lotes de leite padronizado quanto aos teores de gordura e sólidos não gordurosos. Os níveis médios de microrganismos mesófilos e psicrotróficos do produto em pó foram 7,8 X $10^{1}$ e 4,0 $\times 10^{1}$ UFC/g, respectivamente, sendo que estes valores estiveram correlacionados significativamente $(\mathrm{P}<0,05)$ com as contagens de mesófilos e psicrotróficos do leite cru (níveis médios de 8,1 x $10^{6}$ e $1,8 \times 10^{7} \mathrm{UFC} / \mathrm{g}$, respectivamente). Observou-se, também, uma correlação significativa $(\mathrm{P}<0,05)$ entre a contagem de psicrotróficos do leite cru e o teor de acidez titulável do produto em pó, cujos valores variaram de 0,15 a 0,19\% (em ácido lático). As amostras de leite em pó produzido a partir de leite cru contendo níveis elevados de psicrotróficos apresentaram maiores índices de insolubilidade, porém, a correlação entre estes parâmetros não foi significativa. Discute-se a importância do controle das condições higiênicas do leite cru, como instrumento fundamental para garantir a qualidade do produto em pó oferecido ao consumo.

Palavras-chave: leite em pó, qualidade microbiológica, qualidade físico-química. 


\section{REFERENCES}

1. American Dry Milk Institute. Standards for grades of dry milks. Bulletin 916. Chicago, ADMI, 1971.

2. American Public Health Association. Compendium of methods for the microbiological examination of foods. $3^{\text {rd }}$ ed. APHA, Washington, 1992, $1219 \mathrm{p}$.

3. Brandão, S.C.C. Tecnologia da produção de leite em pó - $1^{a}$ parte. Leite e derivados, 17: 49-57, 1994.

4. Cousins, C.M.; Bramley, A.J. Microbiologia de la leche cruda. In: Robinson, R.K. (ed). Microbiologia lactologica. V.1. Acribia, Zaragoza, 1987, p.109-150.

5. Griffiths, M.W.; Phillips, J.D.; West, I.G.; Sweetsur, A.W.M.; Muir, D.D. The quality of skim-milk powder produced from raw milk stored at 2 degree. Food Microbiol., 5: 89-96, 1988.

6. Instituto Adolfo Lutz. Normas Analiticas do Instituto Adolfo Lutz. $3^{\mathrm{a}}$ ed. V.1. IAL, São Paulo, 1985, 533p.

7. Johnson, R.; Bhattacharyya G. Statistics, principles and methods. John Wiley and Sons, New York, 1987.
8. Kwee, W.S.; Dommett, T.W.; Giles, J.E.; Smith, R.A.D.; Roberts, R. Microbiological parameters during powdered milk manufacture. 2. Relationships and predictability among counts. Aust. J. Dairy Technol., 41: 6-8, 1986.

9. Lewis, M.J. Heat treatment of milk. In: Robinson, R.K. (ed). Modern dairy technology. Chapman \& Hall, London, 1993, p.1-60.

10. Lück, H. Control de la calidad de la industria lactologica. In: Robinson, R.K. (ed). Microbiologia lactologica. V.2. Acribia, Zaragoza, 1987, p.255294.

11. Ministério da Agricultura e do Abastecimento. Portaria n. 369, 04 set. 1997. Diário Oficial da União, Brasília, 08 set. 1997, p.19699-19700.

12. Muir, D.D.; Griffiths, M.W.; Phillips, J.D.; Sweetsur, A.W.M.; West, I.G. Effect of the bacterial quality of raw milk on the bacterial quality and some other properties of low-heat and high-heat dried milk. J. Soc. Dairy Technol., 39: 115-118, 1986.

13. Secretaria de Vigilância Sanitária do ministério da Saúde. Portaria n. 451 , 19 set 1997. Diário Oficial da União, Brasília, 22 set.1997. p.2100521012.

14. Spreer, E. Lactologia industrial. $2^{\mathrm{a}}$ ed. Acribia, Zaragoza, 1991, 617p.

15. Woodhall, $\mathrm{M}$. The application of hazard analysis and critical control point system to milk powder manufacture. J. Soc. Dairy Technol., 42: 102-105, 1989. 